\title{
Differential sensitivity of two insect GABA-gated chloride channels to dieldrin, fipronil and picrotoxinin
}

\author{
Hervé Le Corronc *, Philippe Alix, Bernard Hue \\ University of Angers, Laboratory of Neurophysiology, UPRES EA 2647, Faculty of Sciences, 2 boulevard Lavoisier, 49045 Angers cedex, \\ France
}

\begin{abstract}
In the central nervous system of both vertebrates and invertebrates inhibitory neurotransmission is mainly achieved through activation of $\gamma$-aminobutyric acid (GABA) receptors. Extensive studies have established the structural and pharmacological properties of vertebrate GABA receptors. Although the vast majority of insect GABA-sensitive responses share some properties with vertebrate GABAA receptors, peculiar pharmacological properties of these receptors led us to think that several GABA-gated chloride channels are present in insects. We describe here the pharmacological properties of two GABA receptor subtypes coupled to a chloride channel on dorsal unpaired median (DUM) neurones of the adult male cockroach. Long applications of GABA induce a large biphasic hyperpolarization, consisting of an initial transient hyperpolarization followed by a slow phase of hyperpolarization that is not quickly desensitized. With GABA, the transient hyperpolarization is sensitive to picrotoxinin, fipronil and dieldrin whereas the slow response is insensitive to these insecticides. When GABA is replaced by muscimol and cis-4-aminocrotonic acid (CACA) a biphasic hyperpolarization consisting of an initial transient hyperpolarization followed by a sustained phase is evoked which is blocked by picrotoxinin and fipronil. Exposure to dieldrin decreases only the early phase of the muscimol and CACA-induced biphasic response, suggesting that two GABA-gated chloride channel receptor subtypes are present in DUM neurones. This study describes, for the first time, a dieldrin resistant component different to the dieldrin- and picrotoxinin-resistant receptor found in several insect species. (C) 2002 Elsevier Science Ltd. All rights reserved.
\end{abstract}

Keywords: Insect; GABA; Dieldrin; Fipronil; Picrotoxinin

\section{Introduction}

The inhibitory neurotransmitter $\gamma$-aminobutyric acid (GABA) is widely distributed within the central nervous system (CNS) of vertebrates and invertebrates. Vertebrate GABA receptors have been classified into three structurally and pharmacologically distinct subtypes, the $\mathrm{GABA}_{\mathrm{A}}, \mathrm{GABA}_{\mathrm{B}}$ and $\mathrm{GABA}_{\mathrm{C}}$ receptors. The GABA and $\mathrm{GABA}_{\mathrm{C}}$ receptors are coupled to a chloride channel (Barnard et al., 1998; Bormann, 2000; Cherubini and Strata, 1997; Enz and Cutting, 1998; Hevers and Luddens, 1998; Mehta and Ticku, 1999; Sieghart, 2000). Vertebrate $\mathrm{GABA}_{\mathrm{A}}$ receptors are blocked by bicuculline and picrotoxinin and their multiple drug-binding sites are targets of a variety of chemicals, including, for example,

* Corresponding author. Tel.: +33-241-735-211; fax: +33-241735-215.

E-mail address: herve.lecorronc@univ-angers.fr (Hervé Le Corronc). barbiturates, benzodiazepines and alcohols. Vertebrate $\mathrm{GABA}_{\mathrm{C}}$ receptors are selectively activated by cis-4-aminocrotonic acid (CACA) and blocked by picrotoxinin and (1,2,5,6-tetrahydropyridin-4-yl)methylphosphinic acid (TPMPA) (Bormann, 2000) but not affected by bicuculline. $\mathrm{GABA}_{\mathrm{B}}$ subtypes modulate either calcium or potassium channels through a $\mathrm{G}$ protein-linked second messenger system (Chebib and Johnston, 1999; Couve et al., 2000; Kuriyama et al., 2000).

Insect neuronal GABA receptors do not fit well into this classification based on pharmacological properties. In insect neurones GABA elicits inhibitory responses associated with $\mathrm{Cl}$ - and $\mathrm{K}^{+}$conductance changes suggesting that both ionotropic (Anthony et al., 1993; Benson, 1988; Deng, 1995; Hosie et al., 1997; Hue and Callec, 1990) and metabotropic (Amat and Hue, 1997; Bai and Sattelle, 1995; Hue, 1991) receptors are present but the pharmacological profile of these receptors are still not well known. In insects, ligands for mammalian GABA receptors have been less than satisfactory in 
characterizing GABA-gated chloride ion channels. Radioligand binding data and electrophysiological studies show that the vast majority of GABA receptors in insects exhibit "GABA ${ }_{\mathrm{A}}$-like" properties, are subject to allosteric modulation but are insensitive to bicuculline (Anthony et al., 1993; Aydar and Beadle, 1999; Buckingham et al., 1994; Deng, 1995; Gant et al., 1998; Hosie et al., 1997; Lees et al., 1987) and therefore differ from vertebrate $\mathrm{GABA}_{\mathrm{A}}$ and $\mathrm{GABA}_{\mathrm{C}}$ receptors. Most of the information on the structure of convulsant binding sites has been provided from radiolabelled ligand binding data in housefly. These receptor-binding studies indicate that in housefly two "models" for binding-sites may exist. The first "model" hypothesizes the presence of : (i) a GABA and agonist recognition site, (ii) a common site for dieldrin (a cyclodiene insecticide) and for 3,3-bistrifluoromethyl-bicyclo[2.2.1] heptane-2,2-dicarbonitrile (BIDN) a bicyclic dinitrile convulsant, (iii) a $t$-butylbicyclo-phosphorothionate (TBPS) site; and (iv) a common site for fipronil (a phenylpyrazole insecticide) and 4'ethynyl-4-propyl-bicycloorthobenzoate (EBOB) (Deng, 1995; Gant et al., 1998). The exact location of the picrotoxinin binding site(s) is(are) still unknown. The second "model" for binding-sites of convulsants hypothesizes that some non-competitive antagonists bind to an identical site but in different or overlapping orientations (Ozoe and Akamatsu, 2001). These results cannot be generalized to all insects because there is a large variation in the affinity of agonists and antagonists for binding sites due to possible species differences or technical approaches (for reviews see Anthony et al., 1993; Rauh et al., 1990). Differences exist between vertebrate and insect GABA-gated chloride channels; it may be possible to exploit such differences to design more selective insecticides but these receptor proteins in insects need a better pharmacological characterization.

In insects native GABA receptors typically inhibit pre- and postsynaptic neuronal activity by increasing mainly chloride dependent events and are found at central synapses (Hue, 1991, 1998; Hue and Callec, 1990) and on synapse-free cell bodies (extrasynaptic receptors) of neurones (Aydar and Beadle, 1999; Benson, 1988; Bermudez et al., 1991; Cayre et al., 1999; Dubreil et al., 1994; Le Corronc and Hue, 1999). Short applications of GABA, GABA ${ }_{A}$ and $\mathrm{GABA}_{\mathrm{C}}$ agonists evoke a fast transient hyperpolarization selectively blocked by convulsants except bicuculline (Aydar and Beadle, 1999; Benson, 1988; Buckingham et al., 1994). These studies led us to think that only one GABA-gated chloride ion channel receptor subtype was present in the insect CNS. However recent experiments performed on the dendritic tree of giant interneurones (GI) of the cockroach CNS suggest that at least two GABA chloride receptor subtypes operate (Hue, 1998). These two subtypes differ in their sensitivity to picrotoxinin and desensitization process because the "GABA $\mathrm{A}_{\mathrm{A}}$-like" subtypes desensitize more rapidly (Hue, 1991, 1998; Zhang et al., 1994). Specific vertebrate agonists and antagonists are not able to discriminate GABA receptor subtypes in the insect CNS when short application protocols of agonist are used. However, in the cockroach cercal nerve-giant interneuron synapse long-pressure applications of GABA evoke a biphasic response suggesting the presence of several GABA-evoked chloride currents in this insect (Hue, 1998).

The aim of the work presented here is to better pharmacologically characterize native GABA-gated chloride responses to long pressure ejections of GABA, CACA and muscimol. We used dorsal unpaired median (DUM) neurones (for reviews see Lapied et al., 1994; Grolleau and Lapied, 2000; Tribut and Lapied, 1994) for such studies because these neurones respond and recover rapidly to GABA. The DUM neurones are also large, easily accessible to electrophysiological techniques and robust. We show that two GABA-gated chloride responses operate in cockroach and they differ in their sensitivity to dieldrin.

\section{Materials and methods}

All experiments were performed at room temperature $\left(20-23^{\circ} \mathrm{C}\right)$ on adult male cockroaches (Periplaneta americana) reared at $28^{\circ} \mathrm{C}$ in a $12 \mathrm{~h}: 12 \mathrm{~h}$ light:dark cycle.

\subsection{Intracellular recordings}

The cockroaches were dissected dorsally and the terminal abdominal ganglion (TAG), the two cerci and the corresponding cercal nerves XI were isolated. The preparation was placed in the following saline (in $\mathrm{mM}$ ): $\mathrm{NaCl}$ (200), $\mathrm{KCl}$ (3.1) $\mathrm{CaCl}_{2}$ (5), $\mathrm{MgCl}_{2}$ (4), sucrose (50), HEPES (10), pH 7.4. The TAG was carefully desheathed to facilitate penetration of microelectrodes and drugs. The TAG was fixed dorsal side up on the floor of an experimental chamber (volume $300 \mu \mathrm{l}$ ) and was superfused with saline at a rate of $0.3 \mathrm{ml} / \mathrm{min}$. The electrical activity of cell bodies of dorsal unpaired median (DUM) neurones in the TAG was recorded through intracellular microelectrodes with resistance of $50-70 \mathrm{M} \Omega$ when filled with $0.2 \mathrm{M} \mathrm{KCl}-0.3 \mathrm{M} \mathrm{K}$ acetate. Recordings were performed with a VF180 microelectrode amplifier (Biologic, France), the output of which was passed to a digital oscilloscope connected to a graphic printer and a chart recorder. The normal resting potential of DUM neurones was from -50 to $-60 \mathrm{mV}$.

\subsection{Drug application}

GABA, muscimol and CACA were ejected for 2 min in the direction of the cell body under investigation by pressure ejection, using a broken micropipette (diameter: 
20-30 $\mu \mathrm{m})$ connected to a pressure-ejection system (Neurophore BH2, Medical System Corp, Greenvale, NY) delivering repetitive pulses of nitrogen $(20 \mathrm{~ms}$ on, $50 \mathrm{~ms}$ off). The tip of the micropipette was positioned 100-300 $\mu \mathrm{m}$ above the cell body. The agonists were ejected for $2 \mathrm{~min}$ once every $10 \mathrm{~min}$, allowing $8 \mathrm{~min}$ of recovery in between episodes. When DUM neurones were exposed to five succesive ejections of GABA, muscimol or CACA, each separated by a 8 min recovery interval, "run-down" was never observed during the time course of recordings (45-50 min) (not illustrated). In all experiments, the antagonists were bath-applied by gravity flow between the first and second agonist ejections and removed between the third and the fourth ejections. Pressure-ejection has been used for several years in the laboratory (Piek et al., 1987). This method allows fast and controlled applications of small volumes of drugs onto cell bodies or into neuropile. Because insect neurones have a complex structure it could be speculated that responses to ejection may differ to bath-application (i.e. pressure-ejected drugs may reach one part of a neurone while bath-applied drugs act on whole areas of neurones). Therefore in some experiments GABA was bath-applied rather than pressure-ejected to verify the similarities of evoked responses. Under these circumstances GABA was bath-applied for $1 \mathrm{~min}$. When required to be present in the bath, antagonists were also included also in the GABA solution.

\subsection{Chemicals}

Fipronil was kindly provided by Aventis CropScience (Research Triangle Park, NC) for use in this study. CACA and TPMPA were purchased from Tocris (Bristol, UK). Muscimol was obtained from Research Biochemicals International (RBI, Natick, MA). All other compounds were purchased from Sigma Chemicals. The antagonists were first solubilised in DMSO, then added to saline to produce a final concentration of $0.1 \%$ DMSO. Electrophysiological control recordings were not affected by $0.1 \%$ DMSO.

Data are expressed as means \pm 1 S.E.M. The number of DUM cells from which recordings were made is known as " $n$ ". On graphs, error bars are shown when larger than symbols. Although many of the figures show results from single experiments, we confirmed each observation in at least three different preparations.

\section{Results}

\subsection{Effects of bath-application of GABA}

When bath-applied for $1 \mathrm{~min}, 10^{-4}$ or $10^{-3} \mathrm{moll}^{-1}$ GABA induced a large fast hyperpolarization (Fig. 1). The response observed during bath-application of
A
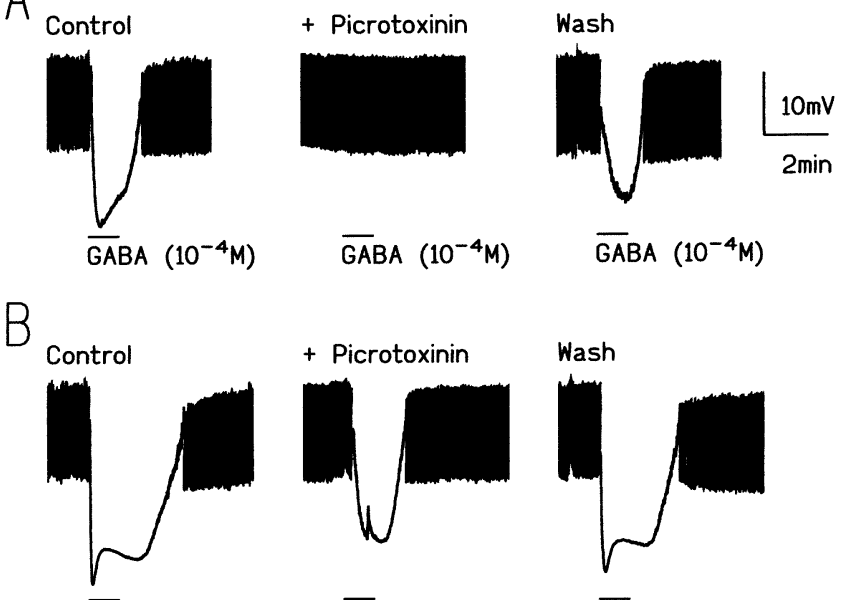

$\overline{G A B A}\left(10^{-3} \mathrm{M}\right)$

$\overline{\mathrm{GABA}}\left(10^{-3} \mathrm{M}\right)$

$\overline{\operatorname{GABA}}\left(10^{-3} \mathrm{M}\right)$

Fig. 1. Effects of bath-application of GABA. (A) Bath-application of $10^{-4}$ moll $^{-1}$ GABA for 1 min (indicated by the horizontal bar) evoked a fast and large hyperpolarization partially (not shown) or fully inhibited by $10^{-4} \mathrm{moll}^{-1}$ picrotoxinin. A wash of 15-20 min was necessary to partially recover the monophasic hyperpolarization. (B) Bath-application of $10^{-3}$ moll $^{-1}$ GABA for 1 min induced a biphasic hyperpolarization. Picrotoxinin $\left(10^{-4} \mathrm{moll}^{-1}\right)$ blocked only the fast transient hyperpolarization. The biphasic characteristic of the GABA response was restored after reintroduction of saline. The thick line represents action potentials which were attenuated because the chart recorder had slow characteristics. Traces A and B were recorded from the same preparation and are both shown on the same scale.

$10^{-4}$ moll $^{-1}$ GABA often showed a repolarization suggesting that desensitisation occured (Fig. 1A). In the presence of $10^{-4} \mathrm{moll}^{-1}$ picrotoxinin, the effect of $10^{-4} \mathrm{moll}^{-1}$ GABA was fully (Fig. 1A) or variably blocked (not illustrated). A wash with saline for 15-20 min was necessary to partially reverse the blockade. GABA $\left(10^{-3} \mathrm{moll}^{-1}\right)$ evoked in all cases a biphasic hyperpolarization that consisted of an initial fast transient hyperpolarization followed by partial repolarization (Fig. 1B). This, in turn, gave way to a slower phase of further hyperpolarization. In all experiments the hyperpolarizing effect of $10^{-3} \mathrm{moll}^{-1}$ GABA was partly blocked by picrotoxinin. When picrotoxinin was bath-applied at $10^{-4} \mathrm{moll}^{-1}$ the fast transient response was antagonized but there was only a moderate inhibitory effect on the slow hyperpolarization.

\subsection{Effects of pressure-application of GABA}

To examine GABA responses in the TAG further, GABA was pressure-ejected on DUM neurones in order to be able to limit the duration of GABA action. Ejection for 2 min of $10^{-2}$ moll $^{-1}$ GABA evoked a biphasic hyperpolarization (Fig. 2). The hyperpolarization started almost immediately after the ejection of GABA and consisted of an initial transient hyperpolarization (filled star in Fig. 2A) followed by a sustained phase of hyperpolarization (open star in Fig. 2A). As previously described in 
A
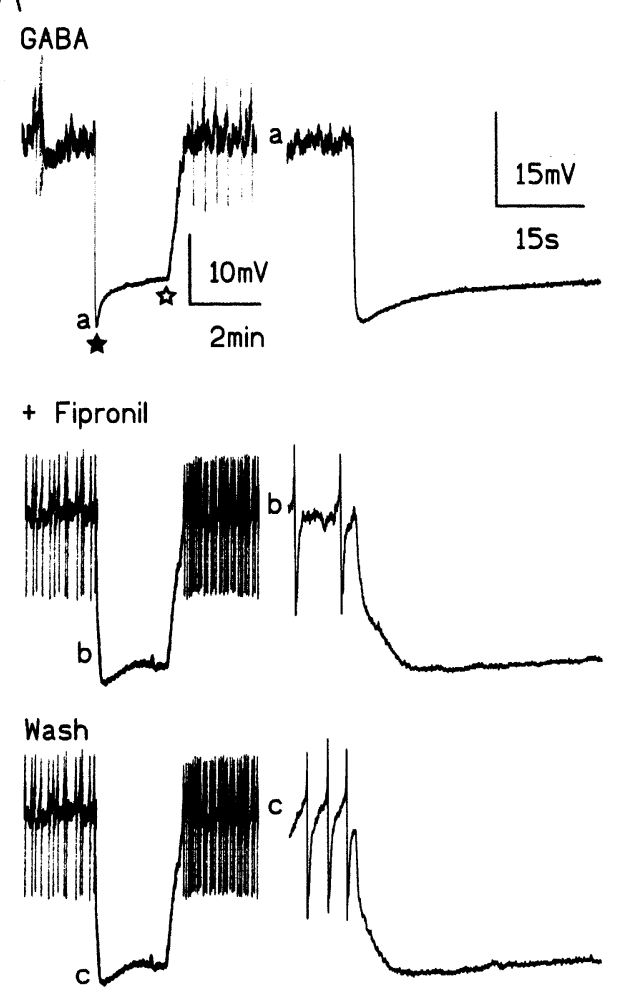

B

ares

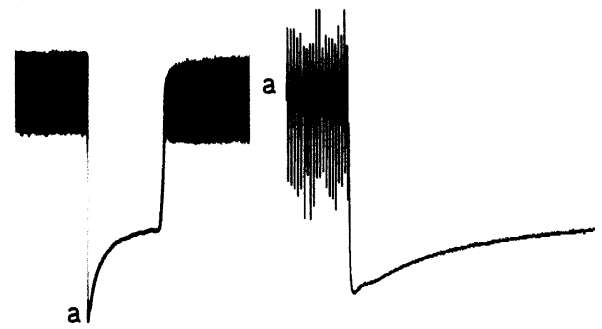

+ Dieldrin

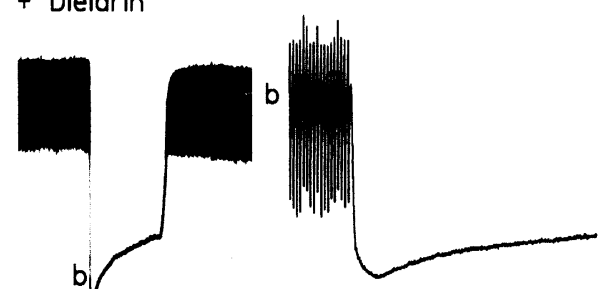

Wash

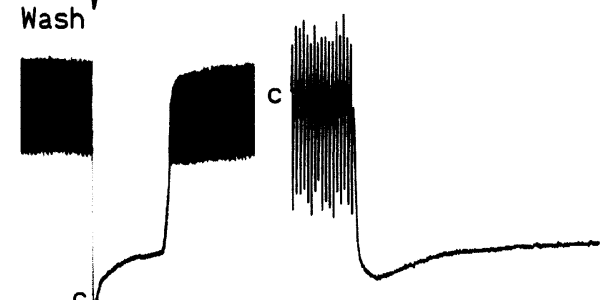

Fig. 2. Effects of pressure-application of GABA. (A) Pressure ejection ( 2 min duration) of $10^{-2}$ moll ${ }^{-1}$ GABA (indicated by the lower horizontal bar) evoked a biphasic hyperpolarization consisted of an initial transient hyperpolarization (filled star) followed by a sustained hyperpolarizing phase (open star).Only the transient phase was reduced by $10^{-6}$ moll ${ }^{-1}$ fipronil. The activity seen in this experiment and marked $a-c$ are shown in more detail in the correspondingly right lettered panels. (B) $10^{-5}$ moll $^{-1}$ dieldrin had little effect on the response to GABA. In (A) and (B) the first (control), third and fifth GABA responses were shown (see materials and methods). The results were recorded from two different preparations.

DUM neurones (Le Corronc and Hue, 1999) the biphasic response evoked by long-lasting ( $3 \mathrm{~min})$ cyclic $(20 \mathrm{~ms}$ on, $40 \mathrm{~ms}$ off) pressure microejection of GABA $\left(10^{-2}\right.$ moll ${ }^{-1}$ ) was poorly affected by $10^{-4}$ moll $^{-1}$ picrotoxin. Picrotoxin reduced the fast transient hyperpolarization but had no effect on the slow hyperpolarizing phase. As shown in Fig. 2, fipronil $\left(10^{-6} \mathrm{moll}^{-1}\right)$ and dieldrin $\left(10^{-5} \mathrm{moll}^{-1}\right)$ also had little inhibitory effect on this late hyperpolarizing phase. These results support the hypothesis that on DUM neurones two different GABA responses can be evoked: a picrotoxinin, fipronil and dieldrin-sensitive GABA-induced hyperpolarization and a fully picrotoxinin, fipronil and dieldrin-insensitive GABA slow hyperpolarization. The amplitude of the picrotoxinin-insensitive response increased with the concentration of GABA and masked the picrotoxinin-sensitive component (not illustrated). We speculate that the picrotoxinin resistant component in DUM neurones of cockroach is due to a metabotropic GABA receptor because the high concentration of picrotoxinin $\left(10^{-4} \mathrm{moll}^{-1}\right)$ used in this study blocked all chloride dependent events evoked by GABA (Hue et al., 1979; Hue, 1991). We were unable to establish any character- istic of neurones that would predict whether they would show a small or large inhibition of the GABA-induced slow hyperpolarization in responses to the blockers. Because the aim of the work presented here was solely to investigate the effect of some antagonists on GABAmediated increases in $\mathrm{Cl}^{-}$conductance, more specific agonists of GABA-gated $\mathrm{Cl}^{-}$receptor were used in the following experiments. CACA and muscimol were chosen because they have been described in the literature as good agonists of such receptors (Hue, 1998; Le Corronc and Hue, 1999).

\subsection{Pharmacological effects of fipronil}

Pressure-ejection of $10^{-4} \mathrm{moll}^{-1}$ muscimol for $2 \mathrm{~min}$ evoked a large biphasic hyperpolarization that was not quickly desensitized (Fig. 3A). This hyperpolarization consisted of an initial transient hyperpolarization followed by a sustained phase of hyperpolarization. The first muscimol (or CACA; see below) response served as a standard. The beginning of the first ejection served as the reference time zero and the magnitudes of transient (filled star in Fig. 3A) and sustained (open star in Fig. 

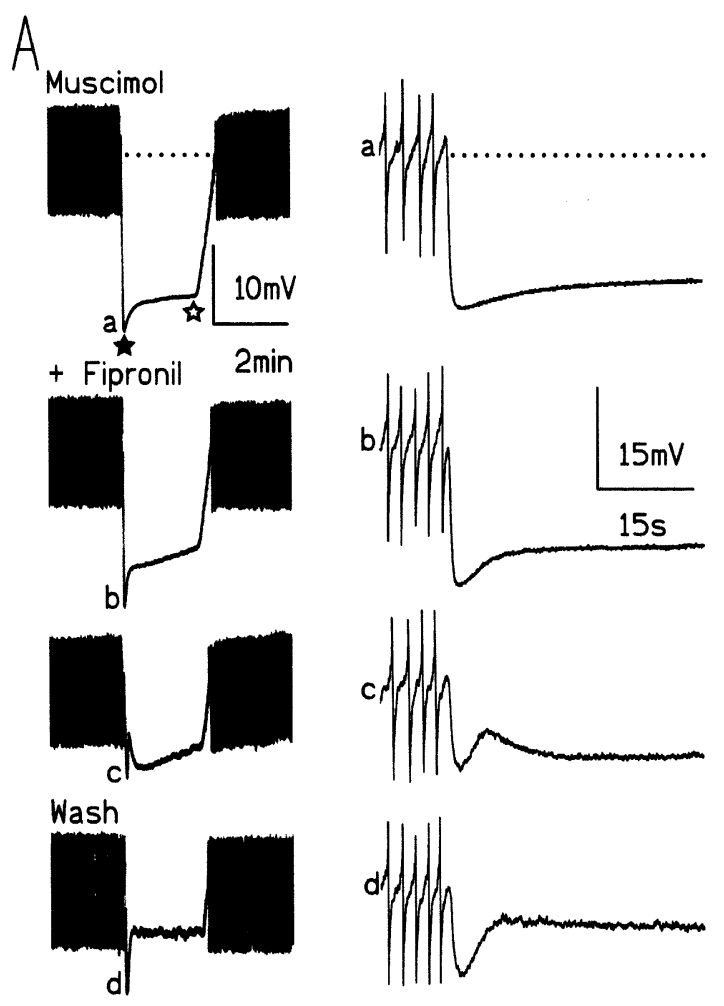

B
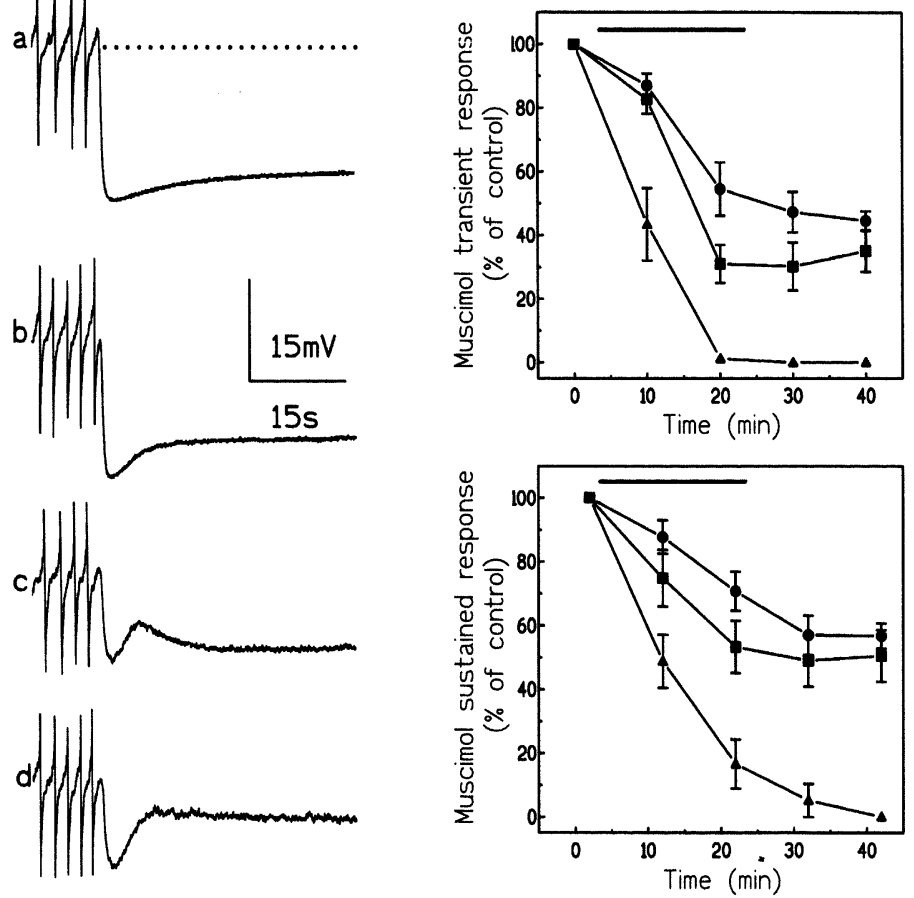

Fig. 3. Effects of fipronil on the biphasic hyperpolarization induced by an ejection of muscimol. (A), left: 2-min period of pressure ejection (indicated by the lower horizontal bar) of $10^{-4} \mathrm{moll}^{-1}$ muscimol caused a biphasic hyperpolarization. The dotted line indicates the resting membrane potential. Fipronil $3 \times 10^{-7}$ moll $^{-1}$ blocked the transient and the sustained hyperpolarization. After washing out the blocker, the normal response was not restored. The activity seen in this experiment and marked $a-d$ are shown in more detail in the correspondingly right lettered panels. The first (control), second, third, and fifth GABA responses are shown. Because the chart recorder and the graphic printer had slow charecteristics, the amplitude of action potentials is attenuated. (B) Graphs show the amplitude of the transient (filled star in A; upper panel in B) and sustained (open star in A; lower panel in B) hyperpolarization in the presence of fipronil as a percentage of those phases of the first muscimol response recorded from the neurone. The first muscimol response began at 0 min. $\bullet: 10^{-7} \operatorname{moll}^{-1}(n=4) ; \mathbf{\square}: 3 \times 10^{-7} \mathrm{moll}^{-1}(n=6) ; \boldsymbol{\Lambda}^{:} 10^{-6}$ moll ${ }^{-1}(n=5)$. The period over which solutions of fipronil were applied is indicated by the horizontal bars.

3A) hyperpolarizations (measured relative to the resting membrane potential of the neurone) of the first biphasic hyperpolarization were taken as $100 \%$. Data points on the graphs in Figs. 3-8 represent average values taken from succesive hyperpolarizing responses recorded from different neurones. TPMPA $\left(10^{-4} \mathrm{moll}^{-1}\right)$ a specific GABA $_{C}$ subtype blocker (Bormann, 2000) was inactive on this biphasic response (not shown). When DUM neurones were exposed to $3 \times 10^{-7} \mathrm{moll}^{-1}$ fipronil during two successive periods of muscimol application, all phases (transient and sustained) of the response underwent a progressive decline (Fig. 3). In order to prevent a technical problem, the flow rate of saline was sufficient to allow fast changing of the bath in less than $5 \mathrm{~min}$. Therefore we suggest that the effect of fipronil is time-dependent. Similar results were obtained in $10^{-7}$ and $10^{-6}$ moll $^{-1}$ fipronil (Fig. 3B). Therefore the results were analysed by comparing features of biphasic responses obtained during the third application of the agonists. In all experiments the magnitude of the fast transient response at $20 \mathrm{~min}$ was compared to the magnitude of the sustained hyperpolarization at $22 \mathrm{~min}$. Fipronil was an effective blocker of the muscimol-induced biphasic hyperpolarization. Hovewer low doses of fipronil $\left(10^{-7}\right.$ and $3 \times 10^{-7} \mathrm{moll}^{-1}$ ) better revealed the biphasic aspect of the response (Fig. 3A). Whatever the concentration of fipronil used, no reverse of its effects occured during the washing period (Fig. 3). These results are similar to those previously published (Grolleau and Sattelle, 2000; Hosie et al., 1995).

Presure-ejection of $10^{-2} \mathrm{moll}^{-1} \mathrm{CACA}$ for $2 \mathrm{~min}$ evoked a biphasic hyperpolarization; as for muscimol this consisted of a fast transient hyperpolarization followed by a sustained phase (Fig. 4A). In the presence of fipronil $\left(10^{-7}\right.$ to $\left.10^{-6} \mathrm{moll}^{-1}\right)$ the effect observed was a reduction of all phases of the CACA response (Fig. 4). Fipronil caused a delayed reduction in the biphasic hyperpolarization. There was no recovery of either of the hyperpolarizing phases after washing fipronil from the preparation. These results and those described in the above paragraph might suggest, among other possibilities, that combining muscimol-fipronil or CACAfipronil did not discriminate between GABA-gated chloride receptor subtypes, or that only one population 


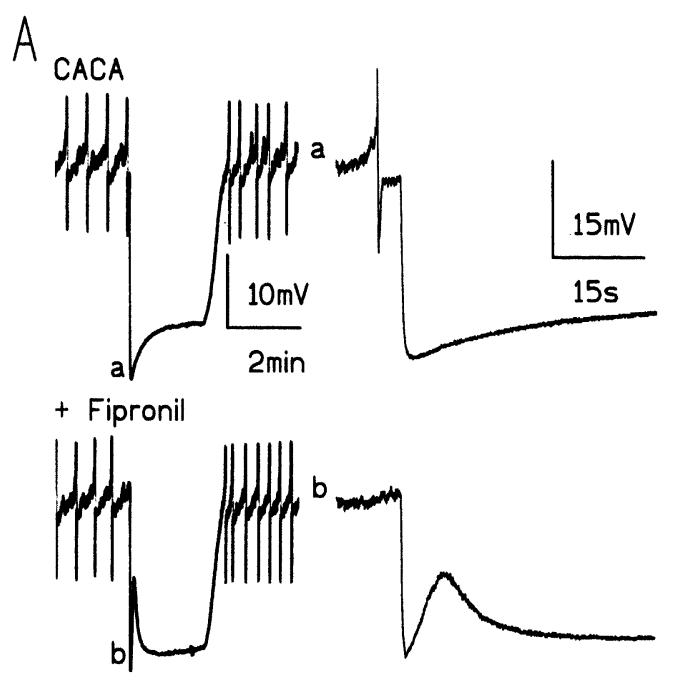

B
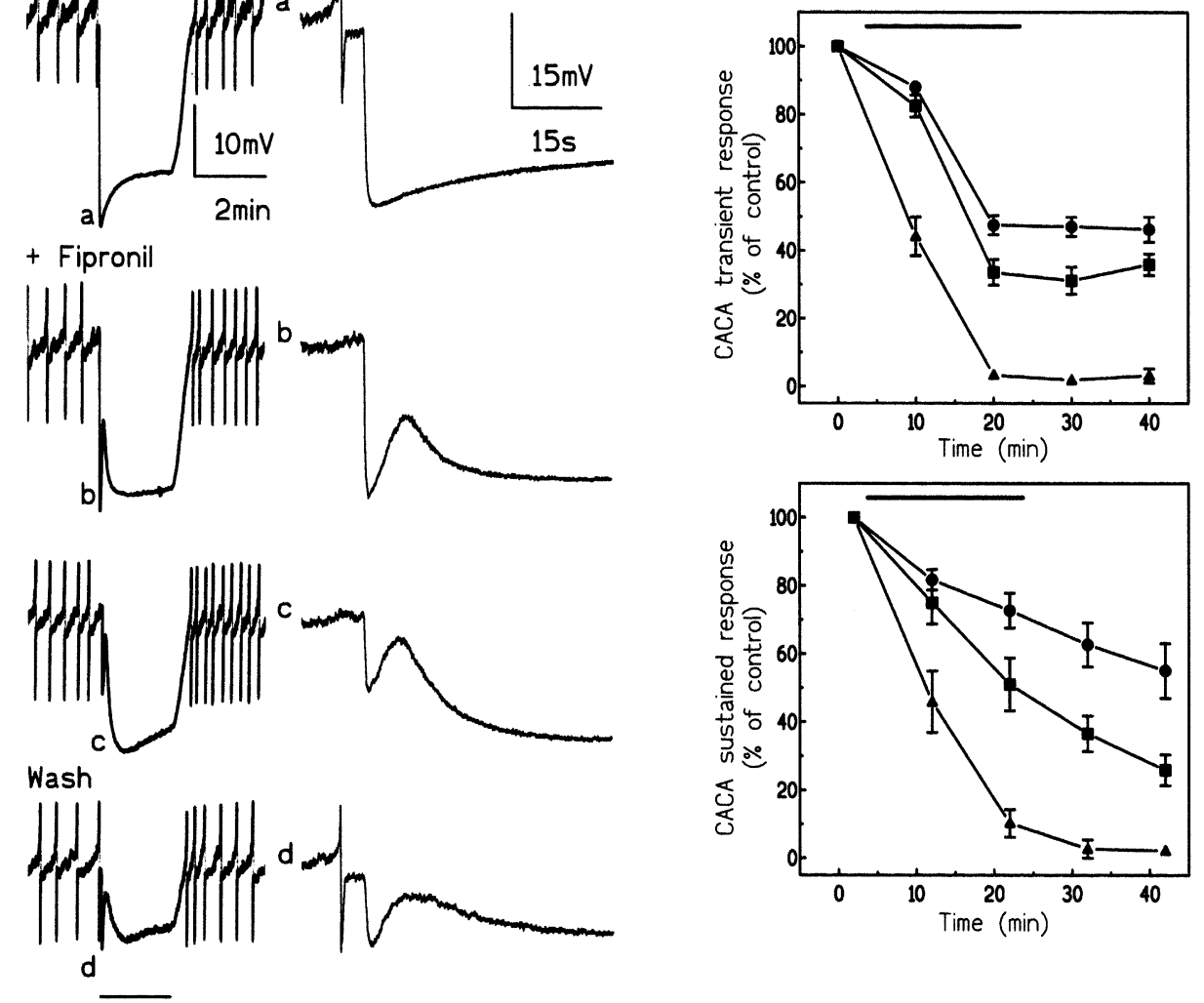

Fig. 4. Pharmacological effects of fipronil on the biphasic hyperpolarization induced by pressure application $\left(2\right.$ min duration) of $10^{-2}$ moll ${ }^{-1}$ CACA. (A) Bath-application of $3 \times 10^{-7}$ moll $^{-1}$ fipronil reduced all phases of the biphasic responses. After the washout of fipronil neither the early transient hyperpolarizing phase nor the sustained hyperpolarization recovered. The first, second, third and fifth responses were shown. (B) Plots show the quantitative effects of fipronil (horizontal bars) on the fast hyperpolarization and on the sustained hyperpolarization. $\bullet: 10^{-7}$ moll ${ }^{-1}(n=8)$; 口: $3 \times 10^{-7} \mathrm{moll}^{-1}(n=12) ; \mathbf{\Delta}: 10^{-6} \mathrm{moll}^{-1}(n=7)$.

of GABA receptors subtypes is present on DUM neurones.

\subsection{Pharmacological effects of picrotoxinin}

Picrotoxinin $\left(3 \times 10^{-7}\right.$ to $\left.10^{-5} \mathrm{moll}^{-1}\right)$ reduced in a dose-dependent manner the biphasic response evoked by muscimol (Fig. 5) and CACA (Fig. 6). In contrast to fipronil no time-dependent effect of picrotoxinin was most often observed, indicating that the flow rate of picrotoxinin was sufficient to reach its receptors in less than 5 min. In $10^{-6}$ moll $^{-1}$ picrotoxinin only the first phase induced by CACA presented a decline, depending on the application time (Fig. 6B). When picrotoxinin was washed from the preparation the biphasic hyperpolarization recovered. The biphasic response was highly reduced in $10^{-5} \mathrm{moll}^{-1}$ picrotoxinin suggesting that both phases of the muscimol- and CACA-induced hyperpolarization are caused by an influx of chloride ions. When the effects of picrotoxinin on the amplitudes of the transient (at $20 \mathrm{~min}$ from the start of the experiment) and sustained (at $22 \mathrm{~min}$ ) phases were compared, no large difference was observed, indicating that picrotoxinin, like fipronil, either does not discrimate between GABA receptors during long pressure-ejection of muscimol and CACA, or that only one GABA receptor subtype is responsible for the biphasic response. Under our experimental conditions, there was a progressive decline in all phases of the biphasic hyperpolarization caused by fipronil but not by picrotoxinin. This decline of the biphasic hyperpolarization was not attributable to either non-specific actions or deterioration in the preparation. Therefore it was difficult to compare hyperpolarizing responses in fipronil and picrotoxinin and it was necessary to use results from different preparations at corresponding times in the experimental protocol. Thus, for example, the amplitude of the transient hyperpolarization induced by muscimol was $41.5 \pm 9.5 \%$ (at $10 \mathrm{~min}$; Fig. 3B) of the control in $10^{-6}$ moll $^{-1}$ fipronil and $38.8 \pm$ $6.6 \%$ (at $10 \mathrm{~min}$; Fig. 5B) in $10^{-6} \mathrm{moll}^{-1}$ picrotoxinin. These results suggested that fipronil and picrotoxinin had the same potency on the muscimol-induced transient hyperpolarization at $10 \mathrm{~min}$. When the measures were made at $20 \mathrm{~min}$, the muscimol-induced transient hyper- 

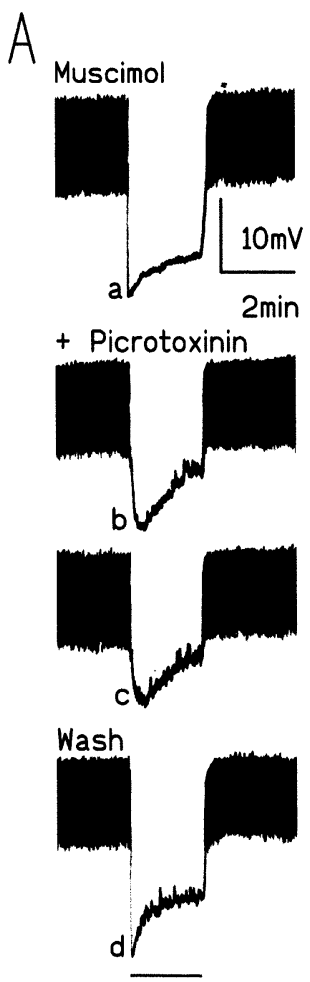
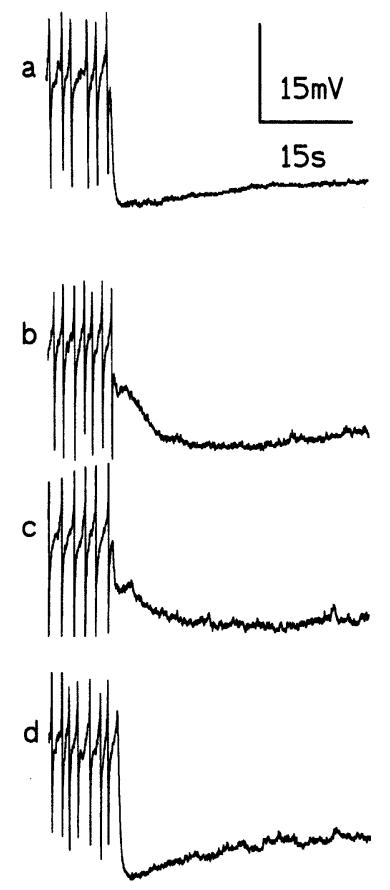
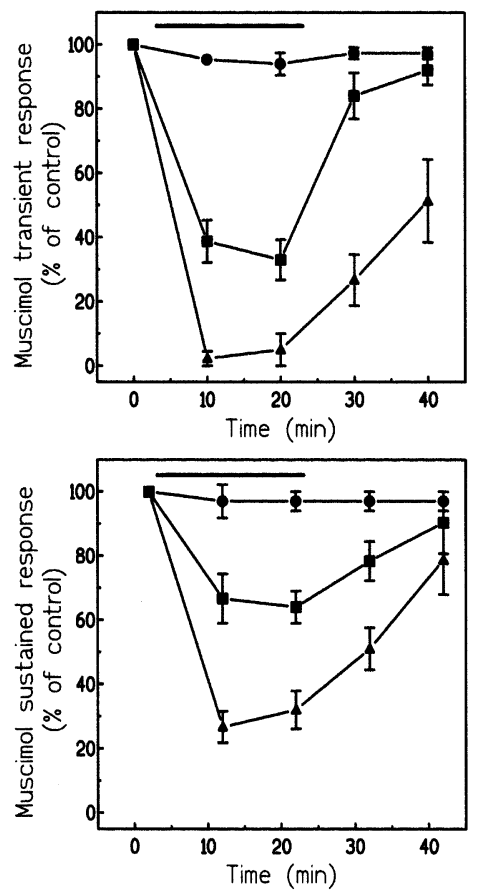

Fig. 5. Reduction of the muscimol-induced biphasic hyperpolarization by picrotoxinin. (A) Bath-application of $10^{-6}$ moll-picrotoxinin reduced both phases of the hyperpolarizing response induced by $10^{-4} \mathrm{moll}^{-1}$ muscimol. The first, the second, the third and the fifth response were shown (B) Plots show the quantitative effects of three concentrations of picrotoxinin (horizontal bar) on the fast (upper panel) and sustained (lower panel) hyperpolarizing phase. $\bullet: 3 \times 10^{-7} \mathrm{moll}^{-1}(n=3)$; $\mathbf{\square}: 10^{-6} \mathrm{moll}^{-1}(n=4) ; \mathbf{\Delta}: 10^{-5} \mathrm{moll}^{-1}(n=4)$.

polarization was $1 \pm 1 \%$ of the control in $10^{-6} \mathrm{moll}^{-1}$ fipronil and $33.0 \pm 6.3 \%$ of the control in $10^{-6} \mathrm{moll}^{-1}$ picrotoxinin indicating that at this time (20 min), fipronil was a more potent blocker than picrotoxinin. The primary interest of the present work was to discriminate between GABA receptor subtypes coupled to chloride channels on DUM neurones. We did not wish to survey the time-dependent effects of blockers on the biphasic hyperpolarizing response induced by long pressure-ejections of muscimol and CACA. However, because of the time-dependent effects reported here, protocols must be fully and carefully described to compare results between them.

\subsection{Pharmacological effects of dieldrin}

Dieldrin $\left(3 \times 10^{-6}\right.$ and $10^{-5}$ moll $\left.^{-1}\right)$ clearly discriminated two chloride responses involved in the muscimol and CACA-induced biphasic hyperpolarization. As shown in Figs. 7 and 8, the fast transient hyperpolarization was slowly attenuated whereas the sustained phase was unchanged. As for fipronil we speculate that dieldrin has a time-dependent effect on the early transient phase because a progressive decline of the first phase was recorded in the presence of dieldrin. A washing period of 20 min was unable to restore the fast transient hyperpolarization and dieldrin did cause a delayed and long- term reduction in the slow response seen on washing (Figs. 7 and 8). No further increase of the dieldrin concentration was possible because of its limited solubility (ffrench-Constant et al., 1993).

\section{Discussion}

We have shown that long pressure-applications of GABA, muscimol and CACA cause a biphasic hyperpolarization in DUM neurones of the cockroach. Muscimol and CACA, two agonists of GABA-gated $\mathrm{Cl}^{-}$receptors, induced a biphasic hyperpolarization that was blocked in fipronil and picrotoxinin, whereas dieldrin reduced only the transient phase of the biphasic response. Our results demonstrate for the first time in an insect neurone that, among compounds tested to date, dieldrin is able to discriminate between two native GABA-gated chloride receptor subtypes present on cockroach DUM neurones.

Our observations clearly show that DUM neurones are highly sensitive to a long application of GABA to which they respond with a large biphasic membrane hyperpolarization. Similar responses have been seen in situ in cell bodies or in the dendritic tree of other identified cockroach neurones. When long ejections (at least $30 \mathrm{~s}$ ) of GABA are performed in the cockroach CNS at the cercal nerve-giant interneurone synapses a biphasic increase of 

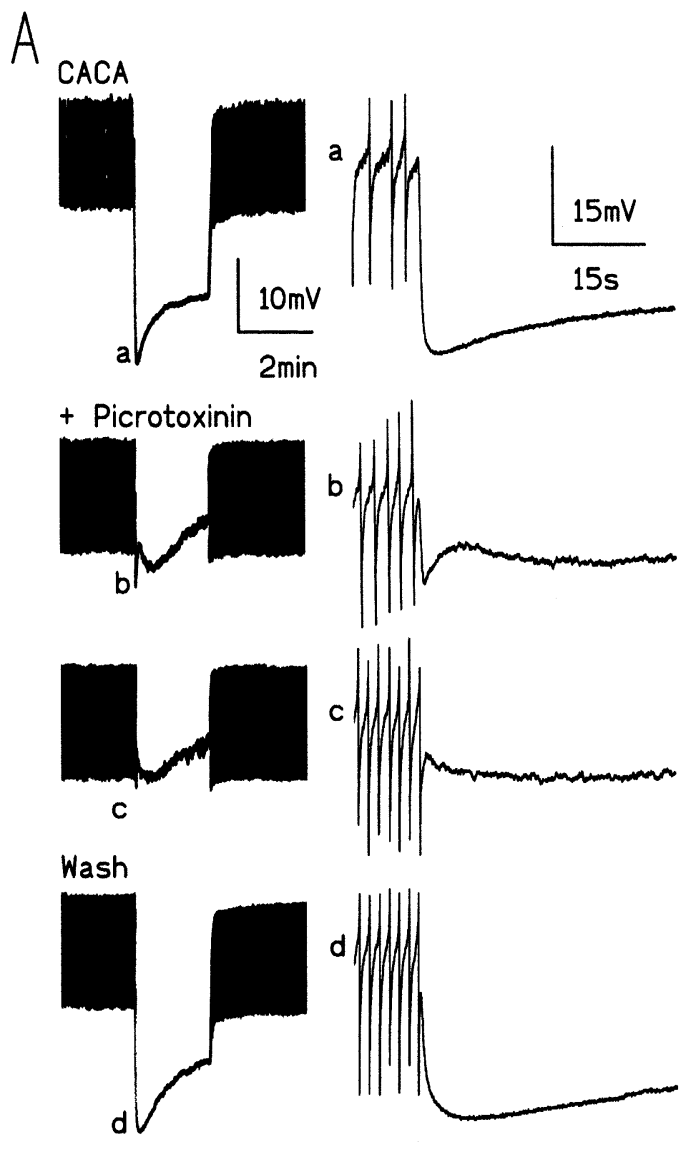
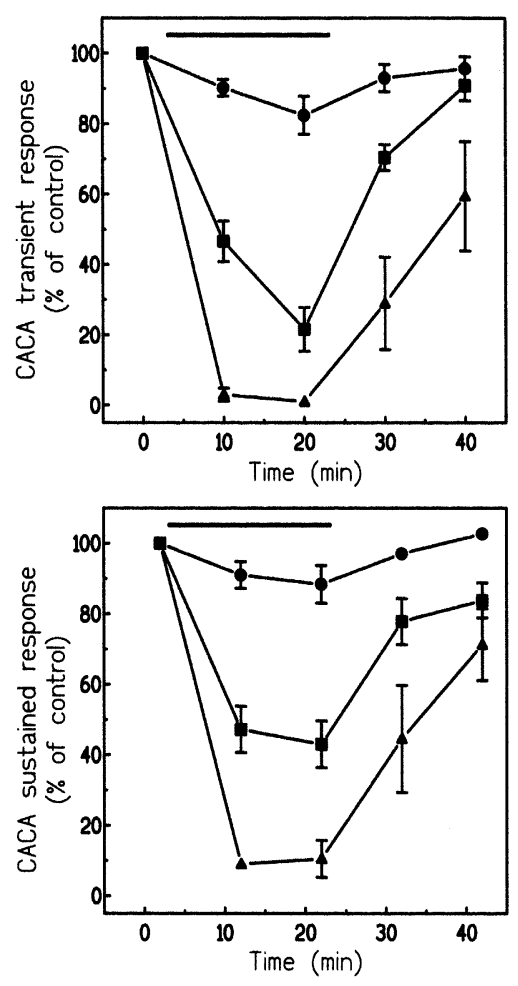

Fig. 6. Representative effects of picrotoxinin on the biphasic hyperpolarization induced by 2 min CACA $\left(10^{-2}\right.$ moll $\left.{ }^{-1}\right)$ pressure ejections $($ lower horizontal bar). (A) Bath-application of $10^{-6} \mathrm{moll}^{-1}$ picrotoxinin reduced all phases of the biphasic response and effects were reversed after the washout. The first (control), second, third, and fifth GABA responses are shown. (B) Plots show the quantitative effects of picrotoxinin (horizontal bars) on the transient and sustained hyperpolarization. $\bullet: 3 \times 10^{-7} \mathrm{moll}^{-1}(n=5) ; \mathbf{\square}: 10^{-6} \mathrm{moll}^{-1}(n=5) ;: \mathbf{\Delta}: 10^{-5} \mathrm{moll}^{-1}(n=5)$.

the membrane conductance occurs: a fast transient conductance change followed by a stable decrease of conductance (Hue, 1991, 1998). Long-lasting applications of GABA onto the cell body of the fast coxal depressor $\left(D_{f}\right)$ motoneurone evoked a fast transient hyperpolarization followed by a slower phase of further hyperpolarization (Le Corronc and Hue, 1999; Sattelle et al., 1998). In cockroach dorsal paired median (DPM) neurones a 4 min bath-application of $10^{-2}$ moll $^{-1}$ GABA induced a biphasic membrane potential change and a blocking in the firing frequency (Amat and Hue, 1997). The amplitude of the biphasic hyperpolarization was larger in DUM neurones when compared to other cockroach neurones. Our results are also generally comparable with observations on the effects of GABA on isolated neuronal cell bodies of insects. With sustained GABA applications the electrical response of Drosophila larvae (Zhang et al., 1994), locust thoracic (Bermudez et al., 1991; von Keyserlingk and Willis, 1992), cricket Kenyon (Cayre et al., 1999), and cockroach embryonic (Bermudez et al., 1991; Shimahara et al., 1987) neurones often reached a peak and then subsequently declined with a fast or a slow time course. Differences found may be due to different receptor densities or receptor types in these different cells.

In this work, only the initial fast transient-hyperpolarization of the GABA response (i.e. that evoked by GABA) was reduced when DUM neurones were treated with blockers. In $10^{-2}$ moll $^{-1}$ GABA the slow response was not reduced by picrotoxinin, fipronil or dieldrin. This was not caused by a displacement of blockers because they are noncompetitive antagonists of GABA receptors in insects (for review see Anthony et al., 1993). Although we have not elucidated the mechanism of the latter hyperpolarizing phase evoked by GABA, we hypothesize that GABA action results from activation of a mixed population of ionotropic and metabotropic receptor subtypes. Support for this suggestion comes from studies of cockroach DPM neurones (Amat and Hue, 1997), GI (Hue, 1991) and $D_{f}$ motoneurones (Bai and Sattelle, 1995), in which $\mathrm{GABA}_{\mathrm{B}}$ agonists were found to trigger the GABA-induced picrotoxinin-resistant component. The resistance of the GABA-induced sustained hyperpolarization to a high concentration of picrotoxinin $\left(10^{-4} \mathrm{moll}^{-1}\right)$, as described previously (Le Corronc and Hue, 1999), and also in this study, suggests 

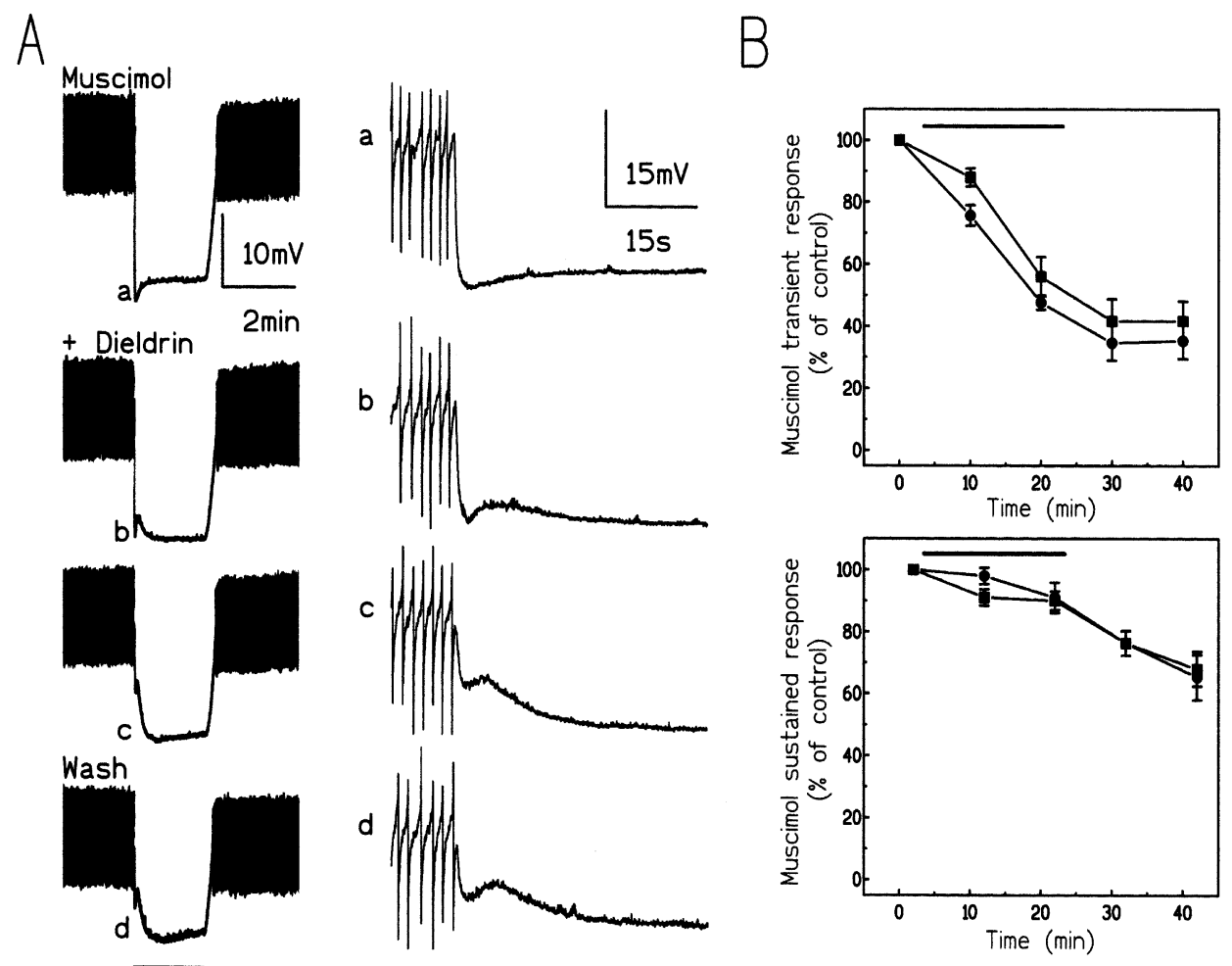

Fig. 7. Effect of dieldrin on the musimol-induced biphasic response. (A) Bath-application of $3 \times 10^{-6}$ moll ${ }^{-1}$ dieldrin reduced only the fast phase of the biphasic potential change induced by a 2 min pressure ejection of $10^{-4} \mathrm{moll}^{-1}$ muscimol. Note the progressive decline of the fast hyperpolarizing response and that this phase did not recover after washing of the insecticide. The first, the second, the third and the fifth applications of muscimol were shown. (B) Size of transient and sustained responses in dieldrin. $\bullet: 3 \times 10^{-6}$ moll $^{-1}(n=3)$; $\mathbf{\square}: 10^{-5}$ moll ${ }^{-1}(n=4)$. The horizontal bars indicate the period over which dieldrin was applied to the bath.

that $\mathrm{GABA}_{\mathrm{B}}$-like receptors are present on DUM neurones in situ.

When pressure-ejected onto DUM neurones, long application of muscimol and CACA resulted in a twocomponent hyperpolarization, consisting of an initial transient and a second, prolonged potential change. The muscimol- and CACA-induced biphasic hyperpolarization were blocked in picrotoxinin and fipronil suggesting that both phases are caused by an influx of chloride ions. Our findings are similar to those obtained with $D_{f}$ motoneurone (Le Corronc and Hue, 1999) in which the CACA-induced membrane hyperpolarization is blocked by $10^{-5}$ moll $^{-1}$ picrotoxin. In our opinion we suggest that these two insecticides are not the best antagonists for a pharmacological discrimination of GABA receptors on DUM neurones because they are not specific for one receptor subtype.

The initial hyperpolarizing component of the biphasic response induced by CACA and muscimol response was reduced by dieldrin. Similar levels of inhibition by $10^{-5}$ moll $^{-1}$ dieldrin in response to GABA-evoked currents after expression in Xenopus oocyte of the Drosophila and Heliothis RDL subunit were also reported by Wolff and Wingate (1998). Over the last 10 years three genes encoding subunits for GABA-mediated increases in $\mathrm{Cl}^{-}$ conductance in Drosophila have been identified and cloned. They are called $R d l$ (resistance to dieldrin), GRD $\left(\mathrm{GABA}_{\mathrm{A}}\right.$ and glycine receptor-like subunit of Drosophila) and LCCH3 (ligand-gated chloride channel homologue 3) (for reviews see Anthony et al., 1993; Hosie et al., 1997; Knipple et al., 1995). Because GABA receptors incorporating the $R d l$ gene products have been established as the primary targets of chlorinated cyclodiene insecticides, most interest has been directed toward the subunit (one of four) encoded by $R d l$ (i.e. RDL subunit). The subunit composition of native receptors in insects have not been determined but the homologs of RDL subunits has been reported in several insect species including American (Thompson et al., 1993) and German (Kaku and Matsumura, 1994) cockroach. Expressed RDL subunits co-assemble to give homo-oligomeric GABA-gated chloride ion channels that are blocked by picrotoxinin, fipronil and dieldrin. Under our experimental conditions, the fast transient-hyperpolarization component of the CACA- and muscimol- induced biphasic response was blocked by fipronil and picrotoxinin and reduced in the presence of dieldrin. These blocking effects were similar to those seen in susceptible insects or after expression of non-resistant RDL subunits (Bloomquist, 2001; Buckingham et al., 1996; ffrenchConstant et al., 1993; Kadous et al., 1983; Wolff and Wingate, 1998). 


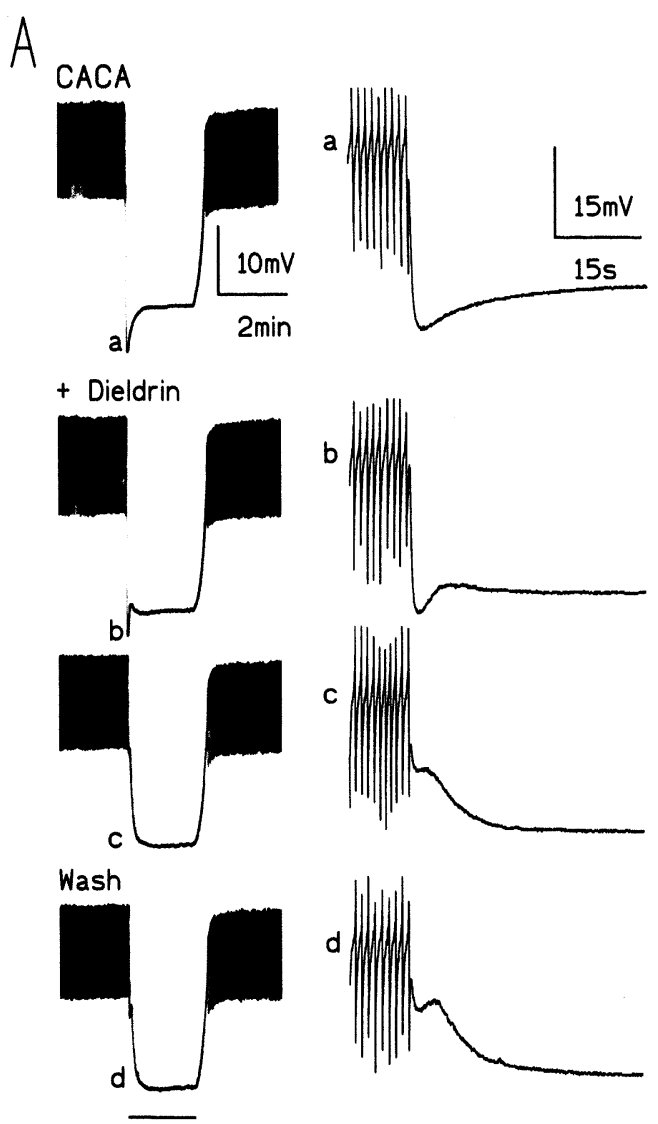

B
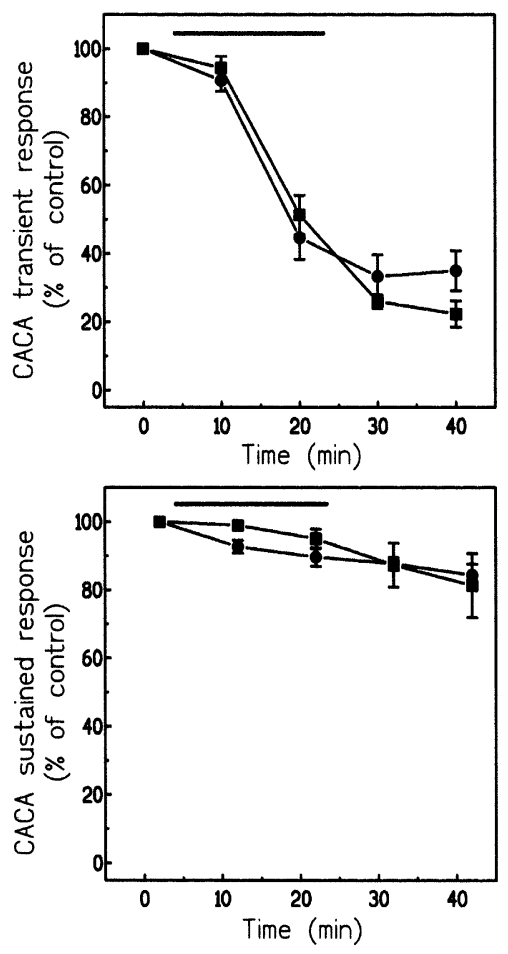

Fig. 8. Effect on the CACA-induced response of dieldrin. (A) 2-min period of pressure ejection of $10^{-2}$ moll ${ }^{-1}$ CACA causes a biphasic hyperpolarization. During bath-application of $3 \times 10^{-6} \mathrm{moll}^{-1}$ dieldrin, the fast transient component progressively declined. After the washout of dieldrin, the early transient hyperpolarizing phase was not restored. The first, the second, the third and the fifth CACA responses were shown. (B) Graphs show the amplitude of the fast (upper panel) phase of the response and the sustained hyperpolarization (lower panel) in the presence of dieldrin. $\bullet$ : $3 \times 10^{-6} \mathrm{moll}^{-1}(n=3) ; \mathbf{\square}: 10^{-5} \mathrm{moll}^{-1}(n=3)$. The horizontal bars indicate the period over which dieldrin was applied to the bath.

In the presence of dieldrin or fipronil, the amplitude of the slow sustained hyperpolarization was unchanged or blocked, respectively. Our results are generally comparable with observations of the effects of dieldrin and fipronil on resistant RDL subunit of Drosophila (Wolff and Wingate, 1998). When mutated, RDL-containing GABA receptor acquire resistance to picrotoxinin and dieldrin (Hosie et al., 1997; ffrench-Constant et al., 1998). Resistance to fipronil in these cases is variable compared with susceptible counterparts, whereas a low resistance ratio to fipronil was reported in sensitive and resistant strains of Blatella germanica (for review see Bloomquist, 2001). It should be noted that the resistance to dieldrin of GABA-gated chloride channels incorporating mutated RDL subunits is associated with resistance to picrotoxinin (Bloomquist, 2001; Buckingham et al., 1996; ffrench-Constant et al., 1993; Kadous et al., 1983; Wolff and Wingate, 1998). Therefore the slow sustained hyperpolarization described here differs to that due to dieldrin- and picrotoxinin-resistant GABA-gated chloride channels. From the present results, we suggest that, in DUM neurones of Periplaneta americana, the biphasic hyperpolarization appears to result from the activation of first, a GABA-gated receptor sensitive to picrotoxinin, fipronil and dieldrin and which is similar to RDL homo-oligomers, and second a slow response supported by a component that is resistant to dieldrin but sensitive to fipronil and picrotoxinin. This hypothesis for the presence of a heterogeneous class of GABA-gated chloride channels in insects is provided by the fact that some pharmacological (Hosie and Sattelle, 1996) and biophysical (Zhang et al., 1995) properties of native insect receptors differ from those of RDL homomultimers, suggesting that RDL subunits should assemble with other but yet unidentified subunits. In Drosophila a single-copy of $R d l$ gene is found but the Drosophila genome contains 12 putative $\mathrm{GABA}_{\mathrm{A}} /$ glycine-like receptor subunit genes (Rubin et al., 2000) among which $R d l$, LCCH3 and GRD genes are the best known. This suggests the possibility that, in this insect, subunits derived from different genes may co-assemble to form homomultimeric and heteromultimeric receptors with different pharmacological properties. The heterologous combination of Drosophila RDL and LCCH3 subunits forms two different GABA receptors (a RDL homomultimeric receptor, and a RDL plus LCCH3 receptor) producing 
a biphasic response following sustained application of GABA (Zhang et al., 1995). Although RDL and LCCH3 subunits are not associated in native GABA receptors (Aronstein et al., 1996), RDL is capable of coassembling with other subunits conferring different pharmacological and biophysical properties on GABA-gated chloride channels (Zhang et al., 1995). We suggest that a similar interaction between different GABA subunits may account for the appearance of the biphasic response recorded from DUM neurones.

A possible alternative explanation to the presence of different GABA receptors is that there is a single channel present on DUM neurones. In vertebrate neurones, picrotoxinin (Dong and Werblin, 1996; Dillon et al., 1995) and dieldrin (Nagata and Narahashi, 1994) have been found to suppress GABA-gated chloride channels after the receptors were activated; the picrotoxinin- and dieldrin-site is exposed by a conformational change initiated by GABA binding to the receptor (use-dependent action). The GABA-induced response to long GABA application fades more rapidly in picrotoxinin and dieldrin with no apparent change of the initial rising rate (i.e. after a transient peak the response declines more rapidly in the presence of blockers). In these experiments performed on vertebrate neurones, the flow rate of perfusion allowed rapid changes for agonists as used in the present study. In insects it appears that picrotoxin (Chen et al., 1994) and certain picrodendrin compounds (Hosie et al., 1996) are able to block the $R d l$ gene products in a similar use-dependent way. In the presence of these blockers, the GABA-induced current faded rapidly whereas the apparent time to peak was unchanged. The apparent potency of such antagonists increased during the course of the GABA response. Furthermore, Drosophila RDL homomeric channels were blocked by fipronil but needed GABA to be present for this block, indicating a use-dependent effect (Grolleau and Sattelle, 2000). Because, in DUM neurones, the CACA- and muscimolinduced biphasic hyperpolarization, in blockers, is not a peak transient hyperpolarization only followed by an accelerated repolarization that might be expected if it resulted from use-dependent action on a GABA receptor with similar pharmacological properties to RDL homooligomers, we argue that the biphasic response is likely to be caused primarily by the presence of more than one GABA receptor. As shown in Figs. 3-8, the reduction of the response at the beginning of the agonist pulse was greater or identical than that observed at the end of the agonist pulse. These findings support our conclusion that more than one GABA-gated chloride channels is present in DUM neurones.

\section{Acknowledgements}

We thank Drs D.F. Bushey and V. L. Salgado for the gift of fipronil.

\section{References}

Amat, C., Hue, B., 1997. Activation of picrotoxin-resistant GABA receptors by GABA and related compounds induces modulation of cockroach dorsal paired median (DPM) neuron firing. Journal of Insect Physiology 43, 1125-1131.

Anthony, N.M., Harrison, J.B., Sattelle, D.B., 1993. GABA receptor molecules of insects. In: Pichon, Y (Ed.), Comparative Molecular Neurobiology. Birkhauser Verlag, Basel, pp. 172-209.

Aronstein, K., Auld, V., ffrench-Constant, R., 1996. Distribution of two receptor-like subunits in the Drosophila CNS. Invertebrate Neuroscience 2, 115-120.

Aydar, E., Beadle, D.J., 1999. The pharmacological profile of GABA receptors on cultured insect neurones. Journal of Insect Physiology 45, 213-219.

Bai, D., Sattelle, D.B., 1995. A GABA B $_{\mathrm{B}}$ receptor on an identified insect motor neurone. Journal of experimental Biology 198, 889-894.

Barnard, E.A., Skolnick, R.W.O., Sieghart, W., Braestrup, G.B.C., Bateson, A.N., Langer, S.Z., 1998. International union of pharmacology. XV. Subtypes of $\gamma$-aminobutyric $\operatorname{acid}_{\mathrm{A}}$ receptors: classification on the basis of subunit structure and receptor function. Pharmacological Reviews 50, 291-313.

Benson, J.A., 1988. Transmitter receptors on insect neuronal somata: GABAergic and cholinergic pharmacology. In: Lunt, G.G. (Ed.), Neurotox 88: Molecular Basis of Drug and Pesticide Action. Elsevier, London, pp. 193-206.

Bermudez, I., Hawkins, C.A., Taylor, A.M., Beadle, D.J., 1991. Actions of insecticides on the insect GABA receptor complex. Journal of Receptor Research 11, 221-232.

Bloomquist, J.R., 2001. GABA and glutamate receptors as biochemical sites for insecticide action. In: Ishaaya, I. (Ed.), Biochemical Sites of Insecticide Action and Resistance. Springer-Verlag, Berlin, pp. $17-41$.

Bormann, J., 2000. The 'ABC' of GABA receptors. Trends in Pharmacological Sciences 21, 16-19.

Buckingham, S.D., Hue, B., Sattelle, D.B., 1994. Actions of bicuculline on cell body and neuropilar membranes of identified insect neurones. Journal of Experimental Biology 186, 235-244.

Buckingham, S.D., Matsuda, K., Hosie, A.M., Baylis, H.A., Squire, M.D., Lansdell, S.J., Millar, N.S., Sattelle, D.B., 1996. Wild-type and insecticide-resistant homo-oligomeric GABA receptors of Drosophila melanogaster stably expressed in a Drosophila celle line. Neuropharmacology 35, 1393-1401.

Cayre, M., Buckingham, S.D., Yagodin, S., Sattelle, D.B., 1999. Cultured insect mushroom body neurons express functional receptors for acetylcholine, glutamate, octopamine, and dopamine. Journal of Neurophysiology 81, 1-14.

Chebib, M., Johnston, G., 1999. The ABC' of GABA receptors: A brief review. Clinical and Experimental Pharmacology and Physiology 26, 937-940.

Chen, R., Belelli, D., Lambert, J.L., Peters, J.A., Reyes, A., Lan, N.C., 1994. Cloning and functional expression of a Drosophila $\gamma$-aminobutyric acid receptor. Proceedings of the National Academy of Sciences of the United States of America 91, 6069-6073.

Cherubini, E., Strata, F., 1997. GABA ${ }_{C}$ receptors: a novel receptor family with unusual pharmacology. News in Physiological Sciences 12, 136-141.

Couve, A., Moss, S.J., Pangalos, M.N., 2000. GABA ${ }_{B}$ receptors: a new paradigm in $G$ protein signaling. Molecular and Cellular Neuroscience 16, 296-312.

Deng, Y., 1995. Insecticide binding sites in the house fly head $\gamma$-aminobutyric acid gated chloride-channel complex. In: Clark, M.J. (Ed.), Molecular Action of Insecticides on Ion Channels. American Chemical Society, Washington DC, pp. 230-250.

Dillon, G.H., Im, W.B., Carter, D.B., McKinley, D.D., 1995. Enhancement by GABA of the association rate of picrotoxin and tert-butyl- 
bicyclophosphorothionate to the rat cloned $\alpha 1 \beta 2 \gamma 2$ GABA $_{\mathrm{A}}$ receptor subtype. British Journal of Pharmacology 115, 539-545.

Dong, C.J., Werblin, F.S., 1996. Use-dependent and use-independent blocking actions of picrotoxin and zinc at the $\mathrm{GABA}_{\mathrm{C}}$ receptor in retinal horizontal cells. Vision Research 36, 3997-4005.

Dubreil, V., Sinakevitch, I.G., Hue, B., Geffard, M., 1994. Neuritic GABAergic synapses in insect neurosecretory cells. Neuroscience Research 19, 235-240.

Enz, R., Cutting, G.R., 1998. Molecular composition of $\mathrm{GABA}_{\mathrm{C}}$ receptors. Vision Research 38, 1431-1441.

ffrench-Constant, T.A., Rocheleau, R.H., Steichen, J.C., Chalmers, A.E., 1993. A point mutation in a Drosophila GABA receptor confers insecticide resistance. Nature 363, 449-451.

ffrench-Constant, R.H., Pittendrigh, B., Vaughan, A., Anthony, N., 1998. Why are there so few resistance-associated mutations in insecticide target genes? Philosophical Transactions of the Royal Society of London series B-Biological Sciences 353, 1685-1693.

Gant, D.B., Chalmers, A.E., Wolff, M.A., Hoffman, H.B., Bushey, D.F., 1998. Fipronil: action at the GABA receptor. Reviews in Toxicology 2, 147-156.

Grolleau, F., Lapied, B., 2000. Dorsal unpaired median neurones in the insect central nervous system: Towards a better understanding of the ionic mechanisms underlying spontaneous electrical activity. Journal of experimental Biology 203, 1633-1648.

Grolleau, F., Sattelle, D.B., 2000. Single channel analysis of the blocking actions of BIDN and fipronil on a Drosophila melanogaster GABA receptor (RDL) stably expressed in a Drosophila cell line. British Journal of Pharmacology 130, 1833-1842.

Hevers, W., Luddens, H., 1998. The diversity of $\mathrm{GABA}_{\mathrm{A}}$ receptors. Molecular Neurobiology 18, 35-86.

Hosie, A.M., Baylis, H.A., Buckingham, S.D., Sattelle, D.B., 1995. Actions of the insecticide fipronil, on dieldrin-sensitive and -resistant GABA receptors of Drosophila melanogaster. British Journal of Pharmacology 115, 909-912.

Hosie, A.M., Sattelle, D.B., 1996. Allosteric modulation of an expressed homo-oligomeric GABA-gated chloride channel of Drosophila melanogaster. British Journal of Pharmacology 117, 1229-1237.

Hosie, A.M., Ozoe, Y., Koike, K., Ohmoto, T., Nikaido, T., Sattelle, D.B., 1996. Actions of picrodendrin antagonists on dieldrin-sensitive and -resistant Drosophila GABA receptors. British Journal of Pharmacology 119, 1569-1576.

Hosie, A.M., Aronstein, K., Sattelle, D.B., ffrench-Constant, R.H., 1997. Molecular biology of insect neuronal GABA receptors. Trends in Neurosciences 20, 578-583.

Hue, B., 1991. Functional assay for GABA receptor subtypes of a cockroach giant interneuron. Archives of Insect Biochemistry and Physiology 18, 147-157.

Hue, B., 1998. A picrotoxin-resistant GABA-gated chloride channel receptor subtype in the cockroach central nervous system. Archives of Insect Biochemistry and Physiology 37, 231-238.

Hue, B., Callec, J.J., 1990. Electrophysiology and pharmacology of synaptic transmission in the central nervous system of the cockroach. In: Huber, I., Masler, E.P., Rao, B.R. (Eds.), Cockroaches as Models for Neurobiology: Applications in Biomedical Researchs. CRC Press, Boca Raton, pp. 149-167.

Hue, B., Pelhate, M., Chanelet, J., 1979. Pre-and post-synaptic effects of taurine and GABA in the cockroach central nervous system. Canadian Journal of Neurological Sciences 6, 243-250.

Kadous, A.A., Ghiasuddin, S.M., Matsumura, F., Scott, J.G., Tanaka, K., 1983. Diffrence in the picrotoxinin receptor between the cyclodiene-resistant and susceptible strains of the german cockroach. Pesticide Biochemistry and Physiology 19, 157-166.

Kaku, K., Matsumura, F., 1994. Identification of the site of mutation within the M2 region of the GABA receptor of the cyclodieneresistant german cockroach. Comparative Biochemistry and Physi- ology C-Pharmacology Toxicology \& Endocrinology.C 108, 367-376.

von Keyserlingk, H.C., Willis, R.J., 1992. The GABA activated $\mathrm{Cl}^{-}$ channel in insects as target for insecticide action: a physiological study. In: Duce, I.R. (Ed.), Neurotox 91: Molecular Basis of Drug and Pesticide Action. Elsevier, London, pp. 79-104.

Knipple, D.C., Henderson, J.E., Soderlund, D.M., 1995. Structural and functional characterization of insect genes encoding ligand-gated chloride-channel subunits. In: Clark, J.M. (Ed.), Molecular Action of Insecticides on Ion Channels. American Chemical Society, Whashington DC, pp. 207-215.

Kuriyama, K., Hirouchi, M., Kimura, H., 2000. Neurochemical and molecular pharmacological aspects of the $\mathrm{GABA}_{\mathrm{B}}$ receptor. Neurochemical Research 25, 1233-1239.

Lapied, B., Sinakevitch, I., Grolleau, F., Hue, B., 1994. DUM neurons in the cockroach TAG: Morphological electrophysiological aspects. In: Borkovec, A.B., Loeb, M.J. (Eds.), Insect Neurochemistry and Neurophysiology. CRC Press, Boca Raton, pp. 101-104.

Le Corronc, H., Hue, B., 1999. A native picrotoxin-resistant GABAgated chloride channel receptor subtype in cockroach neurons. Pesticide Science 55, 1007-1011.

Lees, G., Beadle, D.J., Neumann, R., Benson, J.A., 1987. Rresponses to GABA by isolated insect neuronal somata: pharmacology and modulation by a benzodiazepine and a barbiturate. Brain Research 401, 267-278.

Mehta, A.K., Ticku, M.K., 1999. An update on $\mathrm{GABA}_{\mathrm{A}}$ receptors. Brain Research Reviews 29, 196-217.

Nagata, K., Narahashi, T., 1994. Dual action of the cyclodiene insecticide dieldrin on the $\gamma$-aminobutyric acid receptor-chloride channel complex of rat dorsal root ganglion neurons. Journal of Pharmacology and Experimental Therapeutics 269, 164-171.

Ozoe, Y., Akamatsu, M., 2001. Non-competitive GABA antagonists: probing the mechanisms of their selectivity for insect versus mammalian receptors. Pest Management Science 57, 923-931.

Piek, T., Hue, B., Mony, L., Nakajima, T., Pelhate, M., Yasuhara, T., 1987. Block of synaptic transmission in insect CNS by toxins from the venom of the wasp Megascolia flavifrons (Fab). Comparative Biochemistry and Physiology C-Pharmacology Toxicology \& Endocrinology. 87C, 287-295.

Rauh, J.J., Lummis, S.C., Sattelle, D.B., 1990. Pharmacological and biochemical properties of insect GABA receptors. Trends in Pharmacological Sciences 11, 325-329.

Rubin, G.M., Yandell, M.D., Wortman, J.R., Miklos, G.L.G., Nelson, C.R., Hariharan, I.K., Fortini, M.E., Li, P.W., Apweiler, R., Fleischmann, W., Cherry, J.M., Henikoff, S., Skupski, M.P., Misra, S., Ashburner, M., Birney, E., Boguski, M.S., Brody, T., Brokstein, P., Celniker, S.E., Chervitz, S.A., Coates, D., Cravchik, A., Gabrielian, A., Galle, R.F., Gelbart, W.M., George, R.A., Goldstein, L.S.B., Gong, F.C., Guan, P., Harris, N.L., Hay, B.A., Hoskins, R.A., Li, J.Y., Li, Z.Y., Hynes, R.O., Jones, S.J.M., Kuehl, P.M., Lemaitre, B., Littleton, J.T., Morrison, D.K., Mungall, C., O Farrell, P.H., Pickeral, O.K., Shue, C., Vosshall, L.B., Zhang, J., Zhao, Q., Zheng, X.Q.H., Zhong, F., Zhong, W.Y., Gibbs, R., Venter, J.C., Adams, M.D., Lewis, S., 2000. Comparative genomics of the eukaryotes. Science 287, 2204-2215.

Sattelle, D.B., Pinnock, R.D., Wafford, K.A., David, J.A., 1998. GABA receptors on the cell-body membrane of an identified insect motor neuron. Proceedings of the Royal Society of London Series B-Biological Sciences 232, 443-456.

Shimahara, T., Pichon, Y., Lees, G., Beadle, C.A., Beadle, D.J., 1987. Gamma-aminobutyric acid receptors on cultures cockroach brain neurones. Journal of experimental Biology 131, 231-244.

Sieghart, W., 2000. Unraveling the function of GABAA receptor subtypes. Trends in Pharmacological Sciences 21, 411-413.

Thompson, M., Steichen, J.C., ffrench-Constant, R.H., 1993. Conservation of cyclodiene insecticide resistance-associated mutations in insects. Insect Molecular Biology 2, 149-154. 
Tribut, F., Lapied, B., 1994. Distinct types of cholinergic receptors activated by arecoline on in situ and isolated DUM neurons. In: Borkovec, A.B., Loeb, M.J. (Eds.), Insect Neurochemistry and Neurophysiology. CRC Press, Boca Raton, pp. 339-342.

Wolff, M.A., Wingate, V.P.M., 1998. Characterization and comparative pharmacological studies of a functional $\gamma$-aminobutyric acid (GABA) receptor cloned from the tobacco budworm, Heliothis virescens (Noctuidae:Lepidotera). Invertebrate Neuroscience 3, 305-315.
Zhang, H.G., ffrench-Constant, R.H., Jackson, M.B., 1994. A unique amino acid of the Drosophila GABA receptor with influence on drug sensitivity by two mechanisms. Journal of Physiology-London $479,65-75$

Zhang, H.G., Lee, H.J., Rocheleau, T., ffrench-Constant, R.H., Jackson, M.B., 1995. Subunit composition determines picrotoxin and bicuculline sensitivity of Drosophila $\gamma$-aminobutyric acid receptors. Molecular Pharmacology 48, 835-840. 